\title{
EXPERIMENTAL STUDIES ON THE TREATMENT OF STREPTOCOCCAL INFECTIONS WITH HYPERBARIC OXYGENATION
}

\author{
Władysław Wolański ${ }^{1}$, Kazimierz Ulewicz $^{2}$, Brunon Kierznikowicz $^{2}$ \\ 1) Diver Training Centre of the Polish Army, Poland \\ 2) Institute of Maritime Medicine of the Military Medical Academy, Poland
}

\begin{abstract}
The article presents the results of research into the therapeutic effect of hyperbaric oxygenation on bacterial infections performed on an animal model. The studies were performed on Porton mice infected intraperitoneally with haemolysing streptococci and later subjected, over a 3 -day period, to 5 exposures of hyperbaric oxygenation at a pressure of 2.8 ata. Depending on the research group, the treatment was commenced after $24,48,72$ and 96 hours from the moment of infection. Some of the animals died during the experiment 8 and 12 days from the date of infection, selected animals of each group were put to death and subjected to post mortem examination. A statistically significant positive effect of hyperbaric treatment on the survival rate, as well as on the development of complications (liver abscesses), was observed in those animals where the hyperbaric oxygenation was applied at an early stage. In groups where the therapy was initiated later, no positive effect was noted, and the complications tended to develop more rapidly. Key words: oxybarotherapy, animal model, streptococci.
\end{abstract}

\section{ARTICLE INFO}

PolHypRes 2016 Vol. 56 Issue 3 pp. $37-42$

ISSN: $1734-7009$ elSSN: 2084-0535

DOI: $10.1515 /$ phr-2016-0018

Pages: 6, figures: 0, tables: 2

page www of the periodical: www.phr.net.pl

Publisher

Polish Hyperbaric Medicine and Technology Society

\section{Original article}

Originally published in Bulletin of the Military Medical Academy 1977

Date of approval for print in PolHyp Res: 06-09-2016 


\section{INTRODUCTION}

In recent years, numerous research centres have been concentrating on the development of hyperbaric oxygen therapy and, at the same time, on conducting experimental research on the effects thereof on microorganisms and their metabolism [1]. Similarly, the subject of research carried out by many authors, consisted in the investigation of the effect of hyperbaric oxygenation on the course of infections and immunological reactions in both humans and laboratory animals $[2,3,5,8,9]$.

After an initial period of enthusiasm, when the application of hyperbaric oxygenation for medicinal purposes was seen as a great achievement, allowing treatment of a wide number of conditions, internal and infectious diseases, the indications and contraindications for its use were specified in more detail. It was subsequently determined that the best results are obtained in treating gas gangrene, particularly that induced by Clodtridium perfringens bacilli, whereas slightly poorer outcomes were achieved in treating gangrene induced by other anaerobes.

Hyperbaric oxygenation enables the obtainment of more favourable medicinal effects in surgeries and in treating superficial infections to integuments occurring as a result of injuries $[5,7,9]$.

In the literature review prepared by GOTTLIEB in 1971 [3] with regard to the effect of hyperbaric oxygenation on micro-organisms, we observe that in a majority of cases oxygen had an inhibitory effect on in vitro growth of micro-organisms - in particular Escherichia coli, Staphylococcus aureus, Pseudomonas aeruginosa with overpressures above 1.3 ata $\mathrm{O}_{2}$. At the same time a diversified bacterial sensitivity to hyperbaric oxygenation was noted with regard to growth inhibition depending on species and genus.

Literature data indicate that it is also possible to obtain favourable treatment results with hyperbaric oxygenation in streptococcal infections [1], however they still require more detailed studies.

The objective of the work was to conduct preliminary analysis of this topic.

\section{MATERIAL AND METHOD}

The research was carried out on white Porton mice (males and females of body weight between 25-30 grams) with the aim to inducing a general intraperitoneal infection with an 18-hour culture of hemolytic streptococci of group A in the Todd-Hevitt broth, serological type T-3, in strictly defined doses of $0.5 \mathrm{ml}$ containing $11 \times 10^{7}$ micro-organisms calculated per specified quantity in the streptococcus culture [6]. The infectious dose and the manner of administration was previously determined for a separate group of animals.

Infected mice were divided into 3 groups of 30 animals each and treated with hyperbaric oxygenation at an overpressure of 2.8 ata $\mathrm{O}_{2}$ applied during 5 hyperbaric sessions over three consecutive days, with two sessions of 90 minutes conducted at four hour intervals on the first and second day, and 1 session on the third day.

The research was conducted in a hyperbaric chamber equipped with side and upper portholes that has been constructed specifically for small animals. The chamber was designed as a hermetically closed pressure container with a capacity of 30 litres, enabling the application of an overpressures of up to 10 ata.

The chamber enables the obtainment of selected controlled pressures, and thus the compression of experimental animals, maintaining them in hyperbaric conditions for various time spans, as well as slow or fast decompression. The breae valve is equipped with a flowmeter, enabling accurate control of chamber ventilation. The provided pressure gauge ensures constant control of overpressure values inside the chamber.

The chamber is supplied with the gas of choice from the outside or with a compressed breathing mix from high pressure cylinders. Each of the cylinders is connected to the chamber system through the pressure regulator and the main break valve.

Control groups consisted of non-infected animals that were subjected to hyperbaric oxygenation and infected animals that were not treated hyperbarically. The treatment of particular groups was commenced after $24,48,72$ and 96 hours from the moment of infection.

In the course of infection control and treatment the animals were put to death and an autopsy was performed, along with bacteriological cultures of the peritoneal exudation on bases used for streptococci isolation. Moreover, histopathological tests were performed on standard heamatoxilin-eosin stained and Gram-method stained preparations from segments of lungs, heart, liver and kidneys.

Following 8 and 12 days after the infection, in each of the tested groups (treated and non-treated) some specimens were put to death and subjected to post mortem examination. Isolated streptococci were tested with regard to their physiological properties.

For the purpose of determining the effect of hyperbaric oxygenation on the in vitro tested streptococci strain, a single 90-minute exposure was performed on agar plates with an addition of $5 \%$ conserved blood, incubated with an 18-hour culture of haemolytic group A streptococcus of serological type T-3 (the same strain as in the animals), at a dose of $0.05 \mathrm{ml}$ per plate in the dilution of $1 / 100,000$, following a 24 -hour cultivation in an incubator at $37^{\circ} \mathrm{C}$.

The number of cultivated bacterial colonies and their appearance were defined for the plates subjected to hyperbaric oxygenation and the control plates.

\section{RESULTS}

In particular groups a number of animals died in the course of the experiment's duration. Their percentage in relation to group sizes is presented in tab. 1 . 
Percentage animals in relation to group sizes.

\begin{tabular}{|c|c|c|c|c|c|c|c|c|}
\hline & \multicolumn{2}{|c|}{$\begin{array}{l}\text { Group treated after } 24 \\
\text { hours }\end{array}$} & \multicolumn{2}{|c|}{$\begin{array}{l}\text { Group treated after } 48 \\
\text { hours }\end{array}$} & \multicolumn{2}{|c|}{$\begin{array}{l}\text { Group treated after } 72 \\
\text { hours }\end{array}$} & \multicolumn{2}{|c|}{$\begin{array}{l}\text { Group treated after } 96 \\
\text { hours }\end{array}$} \\
\hline & $\mathrm{Hbt}$ & Control & $\mathrm{Hbt}$ & $\begin{array}{l}\text { Not } \\
\text { treated }\end{array}$ & $\mathrm{Hbt}$ & $\begin{array}{l}\text { Not } \\
\text { treated }\end{array}$ & $\mathrm{Hbt}$ & $\begin{array}{l}\text { Not } \\
\text { treated }\end{array}$ \\
\hline $\begin{array}{l}\text { Number } \\
\text { of dead } \\
\text { animals in } \\
\%\end{array}$ & 30 & 50 & 26.6 & 26.6 & 46.6 & 40 & 46.6 & 26.6 \\
\hline
\end{tabular}

Detailed results of hyperbaric oxygenation treatment applied to infected mice depending on the time of treatment commencement following the infection

\begin{tabular}{|c|c|c|c|c|c|c|}
\hline & \multicolumn{2}{|c|}{ Hbo treatment after 24 hours } & \multicolumn{2}{|c|}{ Hbo treatment after 48 hours } & \multicolumn{2}{|c|}{ Hbo treatment after 96 hours } \\
\hline & Hbo & control & Hbo & control & Hbo & control \\
\hline $\begin{array}{ll}\text { Total } & \text { number } \\
\text { of } & \text { infected } \\
\text { mice } & \\
\end{array}$ & 15 & 15 & 15 & 15 & 15 & 15 \\
\hline $\begin{array}{l}\text { Died after } 24 \\
\text { hours }\end{array}$ & 1 & 1 & 1 & 1 & - & - \\
\hline \multirow{2}{*}{$\begin{array}{l}\text { Died up to } 48 \\
\text { hours }\end{array}$} & \multicolumn{6}{|c|}{ HBO exposure $-2 x$} \\
\hline & 1 & 2 & 1 & 1 & 1 & 2 \\
\hline \multirow{2}{*}{$\begin{array}{l}\text { Died up to } 72 \\
\text { hours }\end{array}$} & \multicolumn{2}{|c|}{ HBO exposure $-2 \mathrm{x}$} & \multicolumn{4}{|c|}{ HBO exposure $-2 \mathrm{x}$} \\
\hline & 2 & 2 & 1 & - & 1 & 1 \\
\hline \multirow{2}{*}{$\begin{array}{l}\text { Died after up } \\
\text { to } 96 \text { hours }\end{array}$} & \multicolumn{2}{|c|}{$\underline{\text { HBO exposure }-1 \mathrm{x}}$} & \multicolumn{2}{|c|}{$\underline{\text { HBO exposure }-2 \mathrm{x}}$} & \multicolumn{2}{|c|}{$\underline{\text { HBO exposure }-2 \mathrm{x}}$} \\
\hline & - & 2 & - & - & 2 & - \\
\hline \multirow{4}{*}{$\begin{array}{l}\text { Put to death } \\
\text { after } 8 \text { days }\end{array}$} & \multicolumn{2}{|c|}{$\underline{\text { Total number of dead animals }}$} & \multicolumn{2}{|c|}{ HBO exposure $-1 \mathrm{x}$} & \multicolumn{2}{|c|}{ HBO exposure $-2 \mathrm{x}$} \\
\hline & 4 & 7 & 3 & 2 & 3 & $\overline{1} 1$ \\
\hline & & & & & \multicolumn{2}{|c|}{ Total number of fallen animals } \\
\hline & & & & & 7 & 4 \\
\hline $\begin{array}{l}\text { Put to death } \\
\text { after } 12 \text { days }\end{array}$ & 6 & 3 & 7 & 8 & 3 & 6 \\
\hline
\end{tabular}

Post mortem examinations allowed to observe a high rate of occurrence of liver abscess both in animals treated and those not treated with hyperbaric oxygenation - a more frequent occurrence of liver abscesses was noted in animals not treated with hyperbaric oxygenation. On a blood control plate housing a culture of group A hemolytic streptococci of serological type T-3, an average of 78 bacterial colonies were noted, whereas in the culture on a blood plate exposed to hyperbaric oxygenation only 2 such colonies were confirmed. Moreover, the said colonies indicated a barely demarkated zone of beta haemolysis (smaller as compared to the control group) with no changes in the Griffith test (agglutination with own sera) and biochemical tests.

Statistical analysis [4] of the results presented in the table (obtained with the use of the Student t-test), revealed a statistical significance in the confidence interval of $98 \%$ (alpha $=0.02$ ) within the scope of differences between the subgroups of infected animals and those treated with hyperbaric oxygenation and not subjected to treatment after 24 and 96 hours ( $\mathrm{T}$ calculated in the group of animals treated after 24 hours - 2.7, in the group treated after 96 hours 2.7, whereas $\mathrm{T}$ read from the Student distribution table was equal to 2.6).

\section{DisCUSSION}

On the basis of the conducted studies it is possible to observe a more favourable treatment effect in the cases where the hyperbaric oxygenation was commenced in an early period, i.e. up to 24 hours. When treatment was commenced in a later period, a more rapid infection development was observed despite the application of hyperbaric oxygenation, and at times a reversed effect consisting in quicker death of the animals subjected to treatment.

The above results allow the putting forward of a thesis that an early medicinal outcome of applying hyperbaric oxygenation, to animals with micro-organisms circulating in the blood in the course of infection, may result from its effect first on the streptoccoci proliferating in the blood or body fluids.

This interpretation of the results is supported by the direct effect of In vitro hyperbaric oxygenation on the micro-organisms growing in the culture. The moment the infection was more advanced and the micro-organisms were found in tissues, which was confirmed with a histopathological examination [10], a favourable treatment result was not noted and the hyperbaric exposure as an additional stimulus can have a negative effect that accelerates the death of the animals. The systemic effect of hyperbaric oxygenation that stimulates 
the vegetative adrenergic nervous system and, what follows, has an effect on an increase of complement, opsonin level, etc. [9], which in such conditions is not a factor facilitating the organism's fight with the infection.

The results of histopathological examinations on the material obtained in this experiment will be a subject of a separate work.

\section{BIBLIOGRAPHY}

1. McAllister T., Stark J., Norman J., Ross R.: Hyperbaric oxygen and aerobic microorganisms. In: Hyperbaric Oxygenation. Prec. of the Second Int. Congr. od. by J. Mc A. Ledingham. 1965. Edinbourgh and London;

2. Boerema J., Brummelkamp W., Meijne N. (ed.) - Clinical Application of Hyperbaric Oxygen. Prec. of the First Ist. Congr. September 1963. Amsterdam, London, New York:

Gottleb S.: Effect of hyperbaria oxygen on microorganisms. Ann. Rev. Microb. 1971. 25:111-152;

Krupczyński J., Grzelak E.: Health care statistics. PZWL Warsaw 1957;

5. Moretti G., Fontanesi S., Ghittoni L. - Prospettive attuali di impiego della ossigenaterapia iperbarica. Ann. di Med. Nav. e Trop. 1973. LXXVIII. 1:11-32;

6. Rotta J.- Streptococus pyogenes. Scientific Information. 5/74. Prague 1974;

7. Schreiner H. - Quantitative evaluation of effects of hyperbaric oxygen and antibiotic drugs on Staphylococcus. w Hyperbaric Oxygenation. Prec. of the Second Int. Congr. ed. by J. Mc A., Ledingham, 1965. Edinbourgh and London

8. Tooley A., Watt J. - Hyperbaric oxygen therapy: Review of the present position and experience in the management of Navel patients, J. Rey Nav. Med. Serv. 1968. Vol. 54:101-130;

9. Ulewicz K. - The application of hyperbaric oxygenation in infection treatment. In: The basics of hyperbaric oxygenation, ed. T. Doboszyński i T. Orłowski, Gdynia 1977;

10. Worms R., Reujeau J., Du Buit H. - The effect of a foreign body on the histological response to staphylococcic infection. In: Staphylococci and Staphylococcal Infections. Recent Progress by J. Jeljaszewicz., W. Hrynkiewicz. Warsaw 1973.

Władysław Wolański

Ośrodek Szkolenia Nurków I Płetwonurków Wojska Polskiego

Ul. Rondo Bitwy Pod Oliwa 1

81-103 Gdynia-Oksywie 